\title{
Drugs obtained by biotechnology processing
}

\author{
Hugo Almeida*, Maria Helena Amaral, Paulo Lobão \\ Pharmaceutical Technology Service, Faculty of Pharmacy, University of Porto, Porto, Portugal
}

\begin{abstract}
In recent years, the number of drugs of biotechnological origin available for many different diseases has increased exponentially, including different types of cancer, diabetes mellitus, infectious diseases (e.g. AIDS Virus / HIV) as well as cardiovascular, neurological, respiratory, and autoimmune diseases, among others. The pharmaceutical industry has used different technologies to obtain new and promising active ingredients, as exemplified by the fermentation technique, recombinant DNA technique and the hybridoma technique. The expiry of the patents of the first drugs of biotechnological origin and the consequent emergence of biosimilar products, have posed various questions to health authorities worldwide regarding the definition, framework, and requirements for authorization to market such products.
\end{abstract}

Uniterms: Biotechnology. Recombinant DNA. Hybridoma technique. Bacteria. Antibiotics. Vaccines.

\begin{abstract}
Nos últimos anos, tem aumentado exponencialmente o número de fármacos de origem biotecnológica ao dispor das mais diversas patologias, entre elas destacam-se, os diferentes tipos de cancêr, as doenças infecciosas (ex. vírus AIDS/HIV), as doenças autoimunes, as doenças cardiovasculares, a Diabetes Mellitus, as doenças neurológicas, as doenças respiratórias, entre outras. A indústria farmacêutica tem recorrido a diferentes tecnologias para a obtenção de novos e promissores princípios ativos, como são exemplo a fermentação, a técnica de DNA Recombinante, a técnica de hidridoma, entre outras. A queda das patentes dos primeiros fármacos de origem biotecnológica e o consequente aparecimento dos produtos biossimilares têm colocado diferentes questões às autoridades de saúde mundiais, sobre a definição, enquadramento e exigências para a autorização de entrada no mercado deste tipo de produtos.
\end{abstract}

Unitermos: Biotecnologia. DNA recombinante. Técnica de Hibridoma. Bactérias. Antibióticos. Vacinas.

\section{INTRODUCTION}

The word biotechnology was first used by Karl Ereky (Hungarian agricultural engineer) in 1919, featuring the use of living organisms on a given raw material for the purpose of obtaining a particular product and introducing the concept of genetic change (Fári, Kralovánszky, 2006). Biotechnology is based on scientific knowledge from different disciplines such as Microbiology, Biochemistry, Genetics, Chemistry, Engineering and Computer Science for biological agents such as microorganisms, cells or molecules (enzymes, antibodies, DNA, etc.) to provide goods and ensure services (Bunders et al., 1996).

\footnotetext{
*Correspondence: H. Almeida, Serviço de Tecnologia Farmacêutica, Faculdade de Farmácia, Universidade do Porto, Rua Aníbal Cunha, n.164, 4050-047Porto, Portugal. E-mail.: hperas5@hotmail.com
}

This multidisciplinary approach is the most important characteristic of this scientific field of study in constant evolution.

In recent years, the biotech industry has been remarkable since it is associated with high efficiency production processes, low manpower, low costs, an environmentallyfriendly industry, with low energy consumption and reduced emission of greenhouse gases (Tang, Zhao, 2009). The pharmaceutical industry, in their attempts to discover new molecules, has found an ally in the biotechnology industry, with exponential growth (Bingham, Ekins, 2009). Thus, the biggest global pharmaceutical companies are buying companies linked to biotechnological research and production (Malik, 2009). The aim of this paper was to review the most important biopharmaceuticals, such as blood factors, hormones, cytokines, enzymes, vaccines and monoclonal antibodies. 


\section{BIOTECHNOLOGY PROCESSES}

Current biotechnological processes essentially involve five different groups of organisms: bacteria (e.g. Escherichia coli, Pseudomonas spp. Serratia mascescens, Erwenia herbicola, Lactococcus lactis and Bacillus subtilis), fungi (e.g. Saccharomyces cerevisiae, Pichia and Hansenula, Trichoderma and Aspergilli), plants (e.g. tobacco plant, rape and transgenic potatoes (Tourte, 1998)), insects (e.g. Spodoptra frugiperda) and mammalians (e.g. Chinese hamster ovary cells (CHO), baby hamster kidney cells (BHK) and transgenic animals) (Walsh, Gary, 2003).

The application of different techniques allows changes to be made in microorganisms, in order to highlight a particular feature or increase their production and ultimately the production of new products. For this, conventional genetic techniques such as mutagenesis, fermentation, sexual and parasexual processes or modern techniques such as recombinant DNA techniques or the hybridoma technique, can be used (Ferreira, Sousa, 1998).

\section{Examples of drugs obtained by biotechnology processes}

Biopharmaceutical forms are potent, reactive, unstable and very expensive (Bruggemeier, 2006; Rader, 2008). They have several advantages such as the provision of effective treatments in chronic and uncommon diseases. Recombinant drugs (Factor VIII for hemophilia), offer safer and reduced side effects, improve on existing therapies and can be produced on a large scale by biotechnological processes.

According to the PhRMA (The Pharmaceutical Research and Manufacturers of America), in 2008 some 633 biotechnological therapeutic products were undergoing development for over 100 different diseases, encompassing 254 malignancies, 162 for infectious diseases, 59 for autoimmune diseases, and 34 for the HIV/AIDS virus or related diseases (PhRMA, 2008). In 2008, the FDA approved 31 new biotechnological drugs and by August 2009 a further 12 new biotechnological drugs were approved (e.g. intranasal vaccine against seasonal influenza virus, treatment in adults of moderate and severe rheumatoid arthritis, prevention of blood coagulation in patients with hereditary antithrombin deficiency, etc.) (PhRMA, 2009).

These new drugs are now in daily use for the treatment of chronic and rare diseases, for which there was hitherto no therapeutic or conventional therapies were ineffective.
TABLE I - Some examples of diseases and respective biopharmaceuticals used in treatment

\begin{tabular}{lc}
\hline Disease & Active substance \\
\hline Hepatitis C & Interferon $\alpha$ \\
Multiple Sclerosis & Interferon $\beta$ \\
Renal Cancer & Interleukin \\
Hemophilia & Factor VIII and Factor IX \\
Diabetes & Human Insulin \\
Anemia & Erythropoietin \\
\hline
\end{tabular}

In the future, biopharmaceuticals may be used against the AIDS virus, different types of cancer, asthma, Parkinson's and Alzheimer's disease. There are different groups of biopharmaceuticals, including: antibiotics, blood factors, hormones, growth factors, cytokines, enzymes, vaccines and monoclonal antibodies.

\section{Antibiotics}

Antibiotics are the largest group in terms of economic importance among the products obtained by fermentation. Some examples of antibiotics whose synthesis involved microorganisms include penicillin produced from Penicillium notatum; cephalosporins (usually semisynthetic process) from the genus Streptomyces; chloramphenicol from Streptomyces venezuelae; streptomycin from Streptomyces griseus; cycloserine from Streptomyces orchidaceus; clindamycin from Streptomyces lincolnensis; vancomycin isolated from cultures of Streptomyces orientalis (Nocardia orientalis); teicoplanin from Actinmoplanes teichomyceticus and mupirocin from Pseudomonas fuoresces (Osswald, Guimarães, 2001).

\section{Blood Factors}

Even with identical causes, two types of hemophilia can be distinguished, namely, hemophilia A (the deficient or abnormal element is Factor VIII or antihemophilic factor A) and hemophilia B (the deficient or abnormal element is Factor IX or antihemophilic Factor B) (Steinberg, Raso, 1998a).

These two blood clotting factors are produced by recombinant techniques. The recombinant Factor VIII produced in CHO cells, containing 1438 a.a. is used in the treatment of hemophilia A (a hereditary disease characterized by slow blood clotting and difficulty controlling blood loss) (Bhopale, Nanda, 2005a). Another example is the Factor IX produced in CHO cells, containing 415 a.a. used in the treatment of hemophilia B (Bhopale, Nanda, $2005 \mathrm{~b}$ ). The gene that produces this factor was cloned in a sheep by a Scottish laboratory in 1997, and this sheep 
subsequently produced milk that contained this factor (Steinberg, Raso, 1998b).

In 2009, the FDA approved Atryn ${ }^{\circledR}$ (antithrombin recombinant), the first medicine produced using genetically engineered animals. This protein with anticoagulant and anti-inflammatory properties is produced in the milk of goats that have been genetically modified. Atryn ${ }^{\circledR}$ is used for the prevention of peri-operative and peri-partum thromboembolic events in hereditary antithrombin deficient patients. The European Medicines Agency (EMEA) also announced approval of the first drug produced in an animal bioreactor: Atryn from GTC Biotherapeutics (EMEA, 2011).

\section{Hormones}

In 1982, the FDA approved the first dosage form obtained through biotechnological processes, recombinant human insulin for the treatment of patients with diabetes, using recombinant DNA techniques in the bacteria $E$. coli (Humulin $^{\circledR}$, Novolin ${ }^{\circledR}$, Velosulin ${ }^{\circledR}$ ). Today, recombinant human insulin is available in different concentrations under different forms of therapeutic action (insulin lispro, insulin aspart, insulin glargine - respectively, very fast, fast, long acting) and for different applications (intramuscular, sub-cutaneous, etc.).

The recombinant human growth hormone improved the long-term treatment of children whose body was not producing enough growth hormone. Somatropin is a recombinant human growth hormone, marketed under different brand names such as Saizen ${ }^{\circledR}$, Nutropin ${ }^{\circledR}$, Humatrope $^{\circledR}$ and Serostin ${ }^{\circledR}$.

\section{Growth Factors}

Many Hematopoietic Growth Factors (HGFs) have been isolated, and the understanding of their clinical potential continues to grow. HGFs have had a significant impact on the prevention of infections associated with chemotherapy-induced neutropenia, chemotherapyinduced thrombocytopenia, and chemotherapy-induced anemia. Patients with HIV/AIDS can also been helped by the administration of recombinant HGFs (Foote, 2008).

Erythropoietin, a hormone produced by the kidneys, stimulates the bone marrow to produce red blood cells. The recombinant human erythropoietin (Procrit ${ }^{\circledR}$, Epogen ${ }^{\circledR}$, Eprex $^{\circledR}$, NeoRecormon $\left.^{\circledR}\right)$ may appear in different forms: alpha (produced in $\mathrm{CHO}$ ), beta (produced in $\mathrm{CHO}$ ) and gamma (produced in BHK). This recombinant growth factor is used in the treatment of anemia associated with renal failure, HIV infections, surgery, etc. Erythropoietin alpha is targeted for the treatment of anemia due to chronic renal failure, HIV infection and cancer (Bhopale, Nanda, 2005c).
Another example is Mircera ${ }^{\circledR}$ (beta methoxypolyethyleneglycol-epoetin) used for the treatment of anemia associated with chronic renal failure (Fajardo et al., 2010). On the other hand, Palifermin (Kepivance ${ }^{\circledR}$ ) is very similar to a natural growth factor that exists in the human body, known as keratinocyte growth factor (KGF). Kepivance ${ }^{\circledR}$ stimulates the growth of cells, helping to reduce the incidence, severity and duration of oral mucositis in cancer patients subjected to intensive care (Hille et al., 2010).

\section{Cytokines}

Cytokines are molecules that activate the immune cells (e.g. lymphocytes and macrophages), regulate growth and differentiation of immune cells, also important messengers in cells, influencing the response in inflammation, response immune and tissue repair (Mahmoud, 2007).

Interleukins are molecules that act as leukocytes messengers, for example the interleukin- 2 stimulates $\mathrm{T}$ lymphocytes. IL-2 recombinant interleukin, approved by FDA, produced by E. coli, which differs from the natural interleukin by the alanine absence on the $N$-terminal and by the fact that serine is replaced by cysteine at 125 amino acid 125, as exemplified in aldesleukin (Proleucina ${ }^{\circledR}$ ). This drug is used in the treatment of renal cell cancer, and its effect is proportional to the amount of recombinant drug administered (Bhopale, Nanda, 2005d). There are other drugs that block interleukin, for example, Arcalyst ${ }^{\mathbb{B}}$ (rilonacept) used for the treatment of CAPS - Cryopyrin Associated Periodic Syndromes. This drug blocks a chemical messenger called interleukin-1-beta and interleukin1-alpha.

The recombinant interferons (potent cytokines that act against viruses and against uncontrolled proliferation of cells) exist in three forms: alpha, beta and gamma, and feature a wide variety of applications. The $\alpha$ recombinant interferon is used in patients with Kaposi's sarcoma, hepatitis $\mathrm{B}$, hepatitis $\mathrm{C}$ and renal cell cancer. The $\beta$ recombinant interferon (produced by E. coli containing 165 a.a.) is used in patients with secondary progressive sclerosis, because it inhibits the production of Th1 cytokines and activates the monocytes involved in the immune response (McCoy et al., 2006). Examples of $\alpha$ recombinant interferons are Intron- $\mathrm{A}^{\circledR}$, Roferon- $\mathrm{A}^{\circledR}$ and Actimmume ${ }^{\circledR}$ whereas $\beta$ recombinant interferons include Avonex ${ }^{\circledR}$, Rebif $^{\circledR}$ and Betaseron ${ }^{\circledR}$. Finally, $\gamma$ recombinant interferon (produced by $E$. coli containing 139 a.a.) is used in patients with infections associated with chronic granulomatous disease (Nasihi, 2000).

\section{Enzymes}

Recombinant dornase alpha (formulated in the form 
of an aerosol - Pulmozyme ${ }^{\circledR}$ ) is an enzyme produced by $\mathrm{CHO}$ cells, used in the treatment of patients with cystic fibrosis, a genetic disorder marked by excessive mucous secretions and frequent lung infections (Bryson, Sorkin, 1994).

Another example of a recombinant enzyme is a plasminogen activator, known as alteplase (Activase ${ }^{\circledR}$ ), used to dissolve blood clots formed in the circulatory system, which can cause heart attacks, pulmonary embolisms and strokes (Steinberg, Raso, 1998c). On the other hand, Naglazyme ${ }^{\circledR}$ (Galsulfase) is a form of recombinant enzyme used for the treatment of patients with mucopolysaccharidosis VI (MPS VI or Maroteaux-Lamy). This disease is caused by the lack of an enzyme called B arylsulfatase, required in the degradation of substances, known as glycosaminoglycans (GAGs). If the enzyme is not present, the GAG cannot be degraded and accumulates in cells, causing large head and movement difficulties.

Elaprase $^{\circledR}$ (idursulfase) is another enzyme produced by biotechnological processes used in the treatment of patients with Hunter syndrome (patients are not able to degrade glycosaminoglycans, which gradually accumulates in cells, affecting most organs, causing difficulty breathing and walking) (Okuyama et al., 2010).

Another case of using biotechnology to produce drugs is the production of essential enzymes in patients with Gaucher syndrome type 1 and 3 (a disease characterized by deficiency of the beta-glucosidase enzyme) (Kotulak, 1998). This disease is usually characterized by a neurological disorder that includes mental degeneration and seizures. There are a few effective therapies for treatment including VPRIV ${ }^{\circledR}$ (velaglucerase alpha - a human cell line derived enzyme replacement therapy - for the long-term treatment of type 1 Gaucher disease), the Protalix Biotherapeutics (taliglucerase alpha - a plant cell-expressed recombinant glucocerebrosidase enzyme), Cerezyme $^{\circledR}$ (imiglucerase - produced by recombinant DNA technology using mammalian cell culture, $\mathrm{CHO}$ ) and $\mathrm{Za}-$ vesca $^{\circledR}$ (miglustat -reduces the harmful build up of fatty substances throughout the body by reducing the amount of glycosphingolipids produced by the body - used in patients who cannot be treated with enzyme replacement therapy) (NGF, 2011).

A different enzyme produced using human cell lines is alfagalsidase $\left(\operatorname{Replagal}^{\mathbb{R}}\right)$. This enzyme is a copy of the human enzyme used in enzyme replacement therapy for Fabry's disease (chronic and progressive genetic diseases caused by absence or deficiency of an enzyme called alpha-galactosidase $\mathrm{A}$, responsible for the decomposition of lipids in the body, consequently the lipids accumulate in vital organs causing serious problems) (Ries et al., 2006).

\section{Vaccines}

Currently, vaccines are not only developed against infectious diseases, but also against drug abuse (nicotine, cocaine) and against allergies, cancer and Alzheimer's disease. Despite the success of conventional vaccines, there are still many infectious diseases and other chronic diseases against which no effective vaccine exists. In addition, the growing resistance to the existing arsenal of antibiotics increases the need to develop vaccines against common bacterial infections. It is expected that novel vaccines against several diseases will become available, and in these case recombinant technologies hold great promise (Jiskoot et al., 2008).

Although conventionally produced vaccines are generally harmless, some of them may, rarely, contain infectious contaminants. Vaccines whose active ingredients are recombinant antigens do not carry this slight risk (Steinberg, 1998a).

Vaccines produced by recombinant DNA techniques have been used to combat seasonal influenza virus (Fluarix $^{\circledR}$, Istivac ${ }^{\circledR}$, Fluzone $^{\circledR}$, FluMist $^{\circledR}$, Agriflu $^{\circledR}$ etc.) and hepatitis A and B. The first vaccine against hepatitis B was made from plasma derived from patients with chronic hepatitis $\mathrm{B}$, and a recombinant vaccine whose sole active ingredient is a recombinant antigen has now replaced it (Steinberg, 1998b).

There are also other types of vaccines produced by genetic engineering, using the yeast Saccharomyces cerevisiae for the production of HBsAg or by entering the HBsAg gene in mammalian cells (Recombivax $\mathrm{HB}^{\circledR}$, Engerix $B^{\circledR}$ ) (Laurence, 1997). The Ambirix ${ }^{\circledR}$ vaccine is another example of a bivalent vaccine used to protect against hepatitis A and hepatitis B (diseases affecting the liver) in children aged between 1 and 15 years old, who have no immunity to these diseases. This vaccine consists of inactivated hepatitis A virus (produced in human diploid cells, MRC-5) and surface antigen of hepatitis B (produced in Saccharomyces cerevisiae yeast cells by recombinant DNA technology). Another example of a vaccine used to protect against hepatitis $A$ and $B$ infection is Twinrix ${ }^{\circledR}$, which contains inactivated hepatitis A virus and parts of the hepatitis B virus as active substances (surface antigens obtained by recombinant DNA technology) (FDA, 2010).

On the other hand, the Myobloc ${ }^{\circledR}$ vaccine is a botulinum toxin type $\mathrm{B}$ vaccine for the treatment of cervical dystonia, produced by fermentation using the bacterium Clostridium botulinum type B (Royal, 2003). Botulinum toxin type $A\left(\right.$ Botox $\left.^{\circledR}\right)$ is indicated for the treatment of cervical dystonia. The Botox Cosmetic ${ }^{\circledR}$ is used in adults under 65 years to raise and fix tissue firmness. Another 
example of a vaccine produced by genetic engineering is Dukoral ${ }^{\circledR}$, used in protection against cholera (an extremely serious disease caused by $V$. cholerae, which is contracted from contaminated food or water and causes severe diarrhea). This vaccine contains small amounts of dead cholera bacteria and a part of the cholera toxin called "B subunit" (produced by recombinant DNA) (Steinberg, 1998c).

The Gardasil ${ }^{\circledR}$ vaccine is produced by yeast that has received a gene allowing the production of $\mathrm{L} 1$ protein, and is used for vaccination against precancerous lesions in the genital area (cervix, vulva and vagina), cervical cancer and genital warts secondary to infection caused by types 6, 11, 16 and 18 of the Human Papillomavirus. Further, the vaccine Cervarix ${ }^{\circledR}$ (human papillomavirus bivalent recombinant vaccine - types 16 and 18) is used for the prevention of cervical cancer and cervical intraepithelial neoplasia (CIN) grade 1 and 2 (FDA, 2010).

In March 2009, the FDA approved a vaccine called Ixiaro $^{\circledR}$ (produced in mammalian cells, "Vero cells") in order to prevent Japanese encephalitis.

For the first time in world history, a pandemic (the first pandemic of the XXI century) had a specific vaccine produced in record time (Focetria ${ }^{\circledR}$, Pandemrix ${ }^{\circledR}$, Celva$\left.\operatorname{pan}^{\circledR}\right)$. With this vaccine, the impacts of this pandemic were drastically reduced. The production and marketing of a safe and effective monovalent vaccine to combat the H1N1 virus, in just a few months after it was considered a pandemic, was a major milestone for the pharmaceutical industry and for global public health.

Another example of a recombinant vaccine is being developed against the Ebola virus. This vaccine is very important because this virus kills 50 to $90 \%$ of those it infects (Hoenen et al., 2006). It is also important to mention the international efforts in obtaining combination vaccines for diphtheria, tetanus, Haemophilus influenzae type B, hepatitis B and polio. One such example is the vaccine Infanrix Penta ${ }^{\circledR}$, used in vaccination of children aged under three years, against diphtheria, tetanus, pertussis, hepatitis B and poliomyelitis (Eldred et al., 2006).

In 2010, the vaccine Menveo ${ }^{\circledR}$ was approved for active immunization to prevent invasive meningococcal disease caused by Neisseria meningitidis (groups A,C,Y and $\mathrm{W}-135)$. In the same year the vaccine Prevnar $13^{\circledR}$ was approved for active immunization to prevent invasive meningococcal disease caused by Streptococcus pneumoniae (serotypes 1, 3, 4, 5, 6A, 7F, 9V, 14, 18C, 19A, $19 \mathrm{~F}$ and $23 \mathrm{f}$ - use in children aged 6 weeks to 5 years) and for prevention of otitis media caused by Streptococcus pneumoniae (serotypes $4,6 \mathrm{~B}, 9 \mathrm{~V}, 14,18 \mathrm{C}, 19 \mathrm{~F}$ and $23 \mathrm{~F}$ ) (FDA, 2011).
Malaria, cholera, herpes, lupus, rheumatoid arthritis, tuberculosis, HIV/AIDS, cancer and gastrointestinal diseases are diseases for which effective vaccines are expected to be developed. In 1998, U.S. researchers announced that they had genetically engineered potatoes to produce a "vaccine" against cholera (Arakawa et al., 1998). We can also highlight other vaccines that are on the horizon such as varicella, otitis and acute chronic infectious respiratory diseases such as pneumonia caused by Streptococcus pneumoniae, Haemophilus influenzae type B, parainfluenza virus, rotavirus, Shigella, Vibrio cholerae and certain types of Escherichia coli (Marques, 1996).

\section{Monoclonal antibodies}

Monoclonal antibodies provide targeted immunosuppression that, when used in conjunction with specific maintenance immunosuppressants, may allow more specific therapy and can be used not only for tumor therapy but also in other therapies or diagnoses. In recent years, this group of drugs has undergone more extensive research, and shown a very promising future, as evidenced by the amount of drugs that are already on the market.

Table II lists examples of monoclonal antibodies on the market for the treatment of different pathologies (FDA, 2010).

\section{Expired patents}

Another problem that arises today is the expiry of the first patent medicines produced by biotechnology processes (examples: Intron $A^{\circledR}$, Humulin ${ }^{\circledR}$, Serostim ${ }^{\circledR}$ etc.). The expiry of these biopharmaceutical patents has given rise to a new generation of molecules called biosimilar products (Rosset, 2007). European legislation provides for the Directive 2004/27/EC of April 2004 that similar products are distinguished from generic low molecular weight and should be considered on a case by case basis (Ronco, 2005). Biosimilar products are more complex and less stable than the generic low molecular weight, and the efficacy and safety can only be considered based on the pre-clinical and clinical trials, including post-marketing data/pharmacovigilance (Mellstedt, 2007).

Therefore, the "Committee for Human Medical Products" of the EMEA developed and published, in 2005 and 2006 , specific guidelines for this class of products covering global guidelines, guidelines for quality, non-clinical and clinical trials and specific guidelines for specific product classes, necessary to demonstrate that the biosimilar products are safe and effective. The first biosimilar drug approved by the FDA was Omnitrope (recombinant human growth hormone). 
TABLE II - Examples of monoclonal antibodies on the market and their therapeutic indications

\begin{tabular}{|c|c|c|}
\hline Medicine & Active Substances & Therapeutic Indications \\
\hline Leukoscan $^{\circledR}$ & Sulesomab & Imaging of bone infection or inflammation \\
\hline Verluma ${ }^{\circledR}$ & Nofetumomab & Detection Kit for Lung Cancer \\
\hline ProstaScint $^{\circledR}$ & Capromab Pendetide & Diagnosis of prostate cancer \\
\hline Rituxan $^{\circledR}$ & Rituximab & B cells Non-Hodgkin lymphoma \\
\hline Mabthera $^{\circledR}$ & Rituximab & $\begin{array}{l}\text { Follicular lymphoma, diffuse non-Hodgkin } \\
\text { lymphoma }\end{array}$ \\
\hline Simulect ${ }^{\circledR}$ & Basiliximab & $\begin{array}{l}\text { Reduces the incidence and severity of acute } \\
\text { rejection in kidney transplantation }\end{array}$ \\
\hline Remicade $^{\circledR}$ & Infliximab & $\begin{array}{l}\text { Rheumatoid arthritis, Crohn's disease, } \\
\text { ankylosing spondylitis, psoriasis }\end{array}$ \\
\hline Synagis ${ }^{\circledR}$ & Palivizumab & $\begin{array}{l}\text { Against the Human respiratory syncytial virus } \\
\text { (RSV) }\end{array}$ \\
\hline Zenapax $^{\circledR}$ & Daclizumab & $\begin{array}{l}\text { Reduces the incidence and severity of acute } \\
\text { rejection in kidney transplantation }\end{array}$ \\
\hline
\end{tabular}

Herceptin $^{\circledR}$

Trastuzumab

MabCampath ${ }^{\circledR}$

Alemtuzumab

Humira $^{\circledR}$

Adalimumab

Trudexa $^{\circledR}$

Adalimumab

ReoPro $^{\circledR}$

Erbitux $^{\circledR}$

Raptiva $^{\circledR}$

Zevalin $^{\circledR}$

Avastin $^{\circledR}$

Xolair $^{\circledR}$

Omalizumab

Tysabri $^{\circledR}$

Natalizumab

Vectibix $^{\circledR}$

Panitumumab

Lucentis $^{\circledR}$
Ranibizumab

\section{Breast Cancer}

Chronic Lymphocytic Leukemia

Active rheumatoid arthritis moderate to severe, psoriatic arthritis in adults, severe active Crohn's disease

$$
\text { Rheumatoid arthritis }
$$$$
\text { Antithrombotic }
$$

Metastatic colorectal cancer

Chronic and severe plaque psoriasis

$$
\text { Non-Hodgkin lymphoma }
$$

Advanced cancer of the colon, breast and lung

First humanized therapeutic antibody for the treatment of asthma and the first approved therapy designed to target the antibody $\operatorname{IgE}$

Multiple sclerosis in adults

Metastatic colorectal cancer that has progressed after treatment with other chemotherapy

Wet age-related macular degeneration (AMD)
Chimeric monoclonal antibody against the protein CD20 found on the surface of B cells

Blocks the receptor for IL-2, a protein that simulates proliferation of T-lymphocytes, which play a key role in organ transplant rejection

Blocks the effects of tumor necrosis factor alpha (TNF-alpha)

Targets the fusion protein of RSV, inhibiting its entry into the cell thereby preventing infection

Binds specifically to the alpha subunit (p55 alpha, CD25, or Tac subunit) of the human high-affinity interleukin-2 (IL-2) receptor that is expressed on the surface of activated lymphocytes

Attaches itself to the HER2 receptors on the surface of breast cancer cells blocking them

Locks on to a protein called CD52 (lymphocytes)

TNF inhibitor

TNF inhibitor

Inhibits platelet aggregation

Binds specifically to the extracellular domain of the human epidermal growth factor receptor (EGFR).

Binds to human CD11a

CD20-directed radiotherapeutic antibody

Recognizes and blocks vascular endothelial growth factor A (VEGF-A)

Blocks immunoglobulin E (IgE)

Binds to the cell surface receptors known as alpha-4beta-1 (VLA-4) and alpha-4-beta-7

Specific to the epidermal growth factor receptor (also known as EGF receptor, EGFR, ErbB-1 and HER1 in humans)

Binds to and inhibits all subtypes of vascular endothelial growth factor A (VEGF-A) 
TABLE II - Continuation

\begin{tabular}{|c|c|c|c|}
\hline Medicine & Active Substances & Therapeutic Indications & Mechanism \\
\hline$\overline{\text { Soliris }^{\circledR}}$ & Eculizumab & $\begin{array}{l}\text { Paroxysmal nocturnal hemoglobinemia } \\
\qquad(\mathrm{PNH})\end{array}$ & $\begin{array}{c}\text { Binds to the complement protein } \mathrm{C} 5 \text {, thus inhibiting } \\
\text { terminal complement mediated intravascular } \\
\text { hemolysis in PNH patients }\end{array}$ \\
\hline $\operatorname{Cimzia}^{\circledR}$ & Certolizumab Pegol & $\begin{array}{c}\text { Active moderate to severe rheumatoid } \\
\text { arthritis }\end{array}$ & TNF inhibitor \\
\hline Simponi ${ }^{\circledR}$ & Golimumab & $\begin{array}{l}\text { Moderate to severe rheumatoid arthritis in } \\
\text { adults, psoriatic arthritis in adults }\end{array}$ & TNF inhibitor \\
\hline Ilaris $^{\circledR}$ & Canakinumab & $\begin{array}{l}\text { Treatment of children and adults with CAPS } \\
\text { (Cryopyrin-Associated Periodic Syndromes) }\end{array}$ & Interleukin-1 $\beta$ blocker \\
\hline
\end{tabular}

\section{CONCLUSIONS}

Based on biotechnological processes, new substances with different therapeutic applications, with a central focus on quality of life and public health, have been developed and produced on a large scale. The application of these techniques covers a wide range of drug classes such as antibiotics, blood factors, hormones, hematopoietic growth factors cytokines, enzymes, vaccines and monoclonal antibodies.

Although the benefits of using biotechnology are clearly evident, a number of concerns and criticisms remain regarding the use of some techniques and procedures, albeit ethical, including the creation of complete copies of living beings (cloning), or environmental, especially in the production of varieties of genetically modified living organisms, whose impact on natural ecosystems may never be determined (Goldstein, Thomas, 2004).

The expiry of the first patent medicines obtained by biotechnological processes has given rise to biosimilar products. Specific guidelines for the approval of these products have been defined by regulatory authorities.

\section{REFERENCES}

ARAKAWA, T.; CHONG, D. K. X.; LANGRIDGE, W. H. R. Efficacy of a food plant-based oral cholera toxin B subunit vaccine. Nat. Biotech., v.16, n.3, p.292-298, 1998.

BHOPALE, G.M.; NANDA, R.K. Recombinant DNA expression produts for human therapeutic use. Curr. Sci., v.89, n.4, p.614-622, 2005.

BINGHAM A.; EKINS S. Competitive collaboration in the pharmaceutical and biotechnology industry. Drug Discov. Today, v.14, n.23/24, p.1079-1081, 2009.
BRYSON, H.M.; SORKIN, E.M. Dornase alpha. A review of its pharmacological properties and therapeutic potential in cystic fibrosis. Drugs, v.48, n.6, p.894-906, 1994.

BRÜGGEMEIER, M. Biotechnology - New directions in medicine. 2.ed. Basel: F. Hoffmann, La Roche Ltd., 2006. $68 \mathrm{p}$.

BUNDERS, J.F.G.; HAVERKORT, B.; HIEMSTRA, W. Biotechnology: Building on Farmer's knowledge. London and Basingstoke: Macmillan Education, Ltd, 1996. 240 p.

ELDRED, B.E.; DEAN, A.J.; MCGUIRE, T.M.; NASH, A. Vaccine components and constituents: responding to consumer concerns. MJA, v.184, n.4, p.170-175, 2006.

EUROPEAN MEDICINES AGENCY. EMEA. ATryn ${ }^{\circledR}$. Available at: $<$ http://www.ema.europa.eu/ema/index. jsp?curl=pages/medicines/human/medicines $/ 000587 /$ human_med_000658.jsp\&murl=menus/medicines $/$ medicines.jsp\&jsenabled=true $>$. Accessed on: 03 jan. 2011.

FAJARDO, C.L.D.; ORTEGA M.P.; BARRERA J.C.; GARRIDO M.D.P. Methoxy polyethylene glycol-epoetin beta in the treatment of a patient with chronic kidney disease presenting late-onset hypersensitivity to other epoetins. Nefrologia, v.30, n.3, p.372-373, 2010.

FÁRI, M.G.; KRALOVÁNSZKY, U.P. The founding father of biotechnology: Károly (Karl) Ereky. Int. J. Hortic. Sci. v.12, n.1, p.9-12, 2006.

FERREIRA, W.F.C.; SOUSA, J.C.F. Microbiologia. 1.ed. Lisboa: Lidel-Edições Técnicas, Lda., 1998. v.1, 342 p. 
FOOTE, M. Hematopoietic grow factors. In: CROMMELIN, D. J. A.; SINDELAR, R. D.; MEIBOHM, B. (Eds.). Pharmaceutical technology - Fundamentals and applications. 3.ed. New York, London: Informa, 2008. p. $225-239$.

FOOD AND DRUG ADMINISTRATION. FDA. Drugs Development Approval Process. Available at: <http:// www.fda.gov/Drugs/DevelopmentApprovalProcess/ H ow Drugs a r e D e velopedand A p p roved/ DrugandBiologicApprovalReports/default.htm $>$. Accessed on: 02 jan. 2010.

FOOD AND DRUG ADMINISTRATION. FDA. 2010 Biological License Application Approvals. Available at: < http://www.fda.gov/BiologicsBloodVaccines/ DevelopmentApprovalProcess/BiologicalApprovalsbyYear/ ucm201369.htm>. Accessed on: 03 jan. 2011.

GOLDSTEIN, D.A.; THOMAS, J.A. Biopharmaceuticals derived from genetically modified plants. Q. J. Med., v.97, n.11, p.705-716, 2004.

HILLE, A.; GRÜGER, S.; CHRISTIANSEN, H.; WOLFF, H.A.; VOLKMER, B.; LEHMANN, J.; DÖRR W.; RAVEFRäNK, M. Effect of tumour-cell-derived or recombinant keratinocyte growth factor (KGF) on proliferation and radioresponse of human epithelial tumour cells (HNSCC) and normal keratinocytes in vitro. Radiat. Environ. Biophys., v.49, n.2, p.261-270, 2010.

HOENEN, T.; GROSETH,A.; FALZARANO, D.; FELDMANN, H. Ebola virus: unravelling pathogenesis to combat a deadly disease. Mol. Med., v.12, n.5, p.206-215, 2006.

JISKOOT, W.; KERSTEN, G. F. A.; MASTROBATTISTA, E. Vaccines. In: CROMMELIN, D. J. A.; SINDELAR, R. D.; MEIBOHM, B. (Eds.). Pharmaceutical TechnologyFundamentals and Applications. 3.ed. New York, London: Informa, 2008. p.405-425.

KOTULAK, R. A brave, new world emerging at "biopharms". Chicago Tribune, Feb. $8^{\text {th }}$., p.12, 1998.

LAURENCE R.: LAURENCE X. Bactérias, vírus e fungos. 1.ed. Lisboa: Instituto Piaget Divisão Editorial, 1997. p.73-100.

MAHMOUD, K. Recombinant protein produtin: strategic technology and a vital research tool. Res. J. Cell. Mol. Biol., v.1, n.11, p.9-22, 2007.
MALIK, N.N. Biotech acquisitions by big pharma: Why and What is next. Drug Discov. Today, v.14, n.17/18, p.818$821,2009$.

MARQUES, M.B. Panorama da biotecnologia industrial em saúde na América Latina e Caribe. Bol. Oficina Sanit. Panam., v.121, n.4, p.291-300, 1996.

MASIHI, K.N. Immunomodulatory agents for prophylaxis and therapy of infections. Int. J. Antimicrob. Agents, v.14, n.3, p.181-191, 2000.

MCCOY, L; TSUNODA, I.; FUJINAMI, R.S. Multiple sclerosis and virus induced immune responses: Autoimmunity can be primed by molecular mimicry and augmented by bystander activation. Autoimmunity, v.39, n.1, p.9-19, 2006.

MELLSTEDT, H. Interpretation of the EMEA Guidelines on Similar Biological Medicinal Produts. Eur. J. Hosp. Pharm. Pract., v.13, n.2, p.68-17, 2007.

NATIONAL GAUCHER FOUNDATION. NGF. Treatments/ Pharmas. Available at: < http://www.gaucherdisease.org >. Accessed on: 03 jan. 2011.

OKUYAMA, T.; TANAKA, A.; SUZUKI, Y.; IDA, H.; TANAKA, T.; COX, G. F.; ETO, Y.; ORII, T. Japan Elaprase Treatment (JET) study: idursulfase enzyme replacement therapy in adult patients with attenuated Hunter syndrome (Mucopolysaccharidosis II, MPS II). Mol. Genet. Metab., v.99, n.1, p.18-25, 2010.

OSWALD, W.; GUIMARÃES, S. Terapêutica medicamentosa e suas bases farmacológicas. 4.ed. Porto: Porto Editora, 2001. $1296 \mathrm{p}$.

PHARMACEUTICALRESEARCHANDMANUFACTURERS OF AMERICA. PhRMA. Medicines in development Biotechnology. Available at: <http://www.phrma.org/ images $/ 110308 \% 20$ biotech\%202008.pdf $>$. Accessed on: 24 nov. 2009.

PHARMACEUTICALRESEARCHAND MANUFACTURERS OF AMERICA. PhRMA. New drug approvals in 2008. Available at: $<$ http://www.phrma.org/media/NDA2008. pdf $>$. Accessed on: 24 nov. 2009. 
PHARMACEUTICALRESEARCHAND MANUFACTURERS OF AMERICA. PhRMA. New medicines approved in 2009. Available at: <http://www.phrma.org/files/2009\%20 Approvals\%200820209_web.pdf>. Accessed on: 24 nov. 2009.

RADER, R.A. (Re)defining biopharmaceutical. Nat. Biotechnol., v.26, n.7, p.743-751, 2008.

RIES, M.; CLARKE, J.T.R.; WHYBRA, C. EnzymeReplacement Therapy With Agalsidase Alfa in Children With Fabry Disease. Pediatrics, v.118, n.3, p.924-932, 2006.

RONCO, C. Biosimilars: How similar are they? Int. J. Artif. Organs, v.28, n.6, p.552-553, 2005.

ROSSET, J. EMEA Guidelines on biosimilars and their clinical implications. Kidney Blood Press Res., v.30, n.1, p.13-17, 2007.

ROYAL, M. A. Botulinum toxins in pain management. Phys. Med. Rehabil. Clin. N. Am., v.14, n.4, p.805-820, 2003.
STEINBERG, F.M.; RASO, J. Biotech pharmaceuticals and biotherapy: an overview. J. Pharm. Pharmaceut. Sci., v.1, n.2, p.48-59, 1998.

TANG, W.L; ZHAO, H. Industrial biotechnology: tools and applycations. J. Biotechnol., v.4, n.12, p.1725-1739, 2009.

TOURTE, Y. Engenharia genética e biotecnologias, conceitos e métodos, aplicações à agronomia e às bioindustrias. Lisboa: Instituto Piaget Divisão Editorial, 1998. p.170-178.

WALSH, G. Pharmaceutical biotechnology products approved within the European Union. Eur. J. Pharm. Biopharm., v.55, n.1, p.3-10, 2003.

WHITTINGTON, R.; GOAD, K.L. Alglucerase: A review of its therapeutic use in Gaucher's disease. Drugs, v.44, n.1, p.72-93, 1992.

Received for publication on $27^{\text {th }}$ July 2010 Accepted for publication on $14^{\text {th }}$ February 2011 